$s i t,{ }^{34}$ that a trial judge could not properly explain the meaning of "direct cause," a term which the court equated with "proximate cause," to the jury. ${ }^{35}$

However, even had the jury completely understood the concept of proximate cause, and had the plaintiff so worded his interrogatory, it is doubtful whether this would have made any difference in the jury's answer. Under commonsense principles, one cannot attribute to the jury a subtlety of thought which would distinguish between remote and proximate cause. ${ }^{36}$ When the jury answered plaintiff's interrogatory, it almost assuredly did so with regard to what it considered not "a" cause, but "the" cause.

Thus, in applying the rules of interpretation outlined above, the Ohio court twisted the jury's special finding into a form completely alien to its plain and simple meaning. So long as the courts carry the reconciliation doctrine to the lengths it was carried in the $M c N e e s$ case, the value of the special interrogatory as a check on the power of the jury in rendering a general verdict will be greatly reduced, if not completely subverted.

\title{
STATE REGULATION OF NONRESIDENT ALIEN INHERITANCE-AN ANOMALY IN FOREIGN POLICY
}

Any discussion of the right of nonresident aliens to inherit American property elicits several conflicting considerations. Everyone agrees that, with some exceptions, a testator should be permitted to dispose of his possessions in any way he chooses, and that the interest of a beneficiary should be protected. ${ }^{2}$ However, a feeling persists that devises and bequests should not be permitted to enrich

$341_{54}$ Ohio St. 154,93 N.E. 2 d 672 (1950).

35 The trial court had submitted the following interrogatories:

"No. I-Do you find the driver of the bus was negligent?"

"No. 2-If the answer to interrogatory No. $I$ is 'yes,' of what did his negligence consist?"

"No. 5-Do you find that the plaintiff, Charles Daniel Brady was negligent in any respect which was the direct cause of his injuries?"

"No. 6-If the answer to interrogatory No. 5 is 'yes,' of what did his negligence consist?"

The jury answered No. r, "Yes." The answer to No. 2 was, "negligence on the part of the defendant that door of bus was accidentally opened." No. 5 was answered "Yes," and No. 6, "We find plaintiff was negligent to a lesser degree than defendant, due to his position in the bus." The trial judge then informed the jury that there was no apportionment of negligence in Ohio, and also explained the concept of direct cause. He requested that the jury reconsider and revise its answer to the sixth interrogatory. The foreman asked for interrogatory five as well, stating: "We didn't understand interrogatory No. 5 about the direct cause." The jury then returned with a negative answer to five, making it unnecessary to answer the sixth question. The supreme court held that the judge's explanations were improper and granted a new trial.

${ }^{36}$ The statement of the dissenting judge is instructive here. Note 30 supra.

${ }^{x}$ See McMurray, Liberty of Testation and Some Modern Limitations Thereon, I4 Ill. L. Rev. 536 (rgrg). 
"unfriendly" nations or defeat the aims of American foreign policy. ${ }^{2}$ Notions of fairness lead to the belief that all persons, citizens or not, should have equal opportunities to acquire and inherit property. ${ }^{3}$ On the other hand, distrust of aliens may give rise to a desire to discriminate. ${ }^{4}$ Although these considerations tend to intermingle, it will be helpful to bear each in mind during an examination of what some courts and legislatures have done in withholding property from, or in disinheriting, alien beneficiaries.

\section{I}

New York, in I939, ${ }^{5}$ and New Jersey, in I940, ${ }^{6}$ enacted statutes having the twofold purpose of protecting alien beneficiaries and fulfilling the intent of the testator. ${ }^{7}$ The New York statute provides:

Where it shall appear that a legatee, distributee, or beneficiary of a trust would not have the benefit or use or control of the money or other property due him, or where other special circumstances make it appear desirable that such payment should be withheld, the decree may direct that such money or other property be paid into the Surrogate's Court for the benefit of such legatee, distributee, or beneficiary of a trust....8

The New Jersey act contains substantially the same language. Both laws resulted from legislative indignation at confiscations by National Socialist Germany of property of "racial," religious, and political minoritjes.

German residents of Jewish descent, for example, were effectively prevented from receiving their shares in the estates of relatives who had died abroad.The German consul-general, equipped with a power of attorney, would appear dur-

2 This policy is clearest, of course, in time of war. The Trading With the Enemy Act, 40 Stat. 4 II (I9I7), as amended, 50 U.S.C.A. §§ I-3I (App., I949), prohibits the sending of money or other property to enemy alien devisees and legatees. Difficulties arise when the United States is not at war with the alien's government, because money remitted to "unfriendly" nations may ultimately be used against this country.

3 Most states have enacted statutes removing the rigid common-law restrictions on alien inheritance. Gibson, Aliens and the Law I79-8I (I940). It is questionable, however, whether the states were motivated entirely by a feeling that aliens should be accorded the same treatment as citizens. One factor was the desire to have more aliens come to this country and settle land. Thus, many states permit aliens to inherit real property, but further provide that they must become residents and citizens of the state within a certain period in order to retain the property. See, for example, Ill. Rev. Stat. (I949) c. 6, §§ I, 2 .

4 At common law, aliens were not permitted to inherit real property because it was thought they could not bear proper loyalties to the state. Aliens "are not allowed to have any inheritable blood," said Blackstone, "upon a principle of national or civil policy." 2 Bl. Comm. *249. There were, however, no similar prohibitions on succession to personalty by aliens.

5 N.Y. Surrogate's Court Act (Thompson, Supp., x942) \& 269 .

${ }^{6}$ N.J. Rev. Stat. (Supp., I940) tit. 3 , c. $26, \S$ 2.I.

7 While this comment will refer only to the policy concerning testamentary intent, it should be remembered that a similar consideration governs when property passes by intestacy. Instead of fulfilling the intent of the testator, the legislature or court attempts to implement the "intent" of the intestacy statute.

${ }^{8}$ N.Y. Surrogate's Court Act (Thompson, Supp., r942) \& 269. 
ing the New York probate proceedings to "represent" a beneficiary. 9 The benefit, when transmitted, was somehow channelled into the German treasury. ${ }^{10}$ The testator's wishes had not been followed, and the beneficiary had been disinherited. Some courts refused to allow the consul-general to act as intermediary

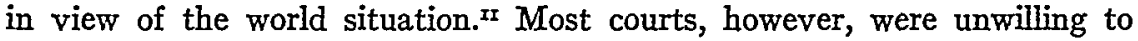
withhold benefits in the absence of legislation. ${ }^{12}$

The New York courts seized upon the new legislative directive, interpreting it broadly and applying it extensively. An early decision held that property should be withheld from a beneficiary whenever confiscation appeared "contingently possible." ${ }_{13}$ Residents of countries under German domination were brought within the statute; thus, benefits from decedents' estates were withheld from most Europeans in the early I940's. At the same time, New York courts denied legacies to residents of the Soviet Union, ${ }^{14}$ on several grounds, including the real or supposed peculiarities of the Soviet system of inheritance, ${ }^{15}$ and the Soviet policy of paying legacies in devalued currency. ${ }^{16}$

The early decisions involving beneficiaries in Soviet-controlled countries clearly express a consideration which the courts did not spell out in other cases. The courts were unwilling to transmit property which might assist the Soviet

9 The treaty with Germany, 44 Stat. 2132 (1923), permits the consular officer to remit the beneficiary's property, but further provides that the consul must "furnish to the authority or agency making distribution through him reasonable evidence of such remission." The New York courts held that this qualification prevented the German consul-general from handling the beneficiary's property. In re Weidberg's Estate, 172 N.Y. Misc. 524, 529, I5 N.Y.S. 2d $252,257-58$ (1939). If it were not shown that the beneficiary was prevented from receiving his property, the consul was permitted to transmit it. In re Blasi's Estate, I72 N.Y. Misc. 587 , I5 N.Y.S. 2d 682 (I939). See 4 Hackworth, Digest of International Law $\$ 443$ (I942); Santovincenzo v. Egan, 284 U.S. 30 (I93r).

${ }^{30}$ In re Weidberg's Estate, I72 N.Y. Misc. 524, I5 N.X.S. 2d 252 (1939). Consult Hollander, Confiscation, Aggression, and Foreign Funds Control in American Law 127-28 (I942).

Ix The Pennsylvania courts went furthest in protecting alien beneficiaries without the help of legislation. One court, speaking of the beneficiaries, declared: "If nobody else is going to protect them, the law of Pennsylvania will." In re Stede's Estate, 38 Dist. \& Co. (Pa.) 209, 212 (1940). See Hollander, op. cit. supra note Io, at I24-26; In re Little's Estate, 43 Dist. \& Co. (Pa.) 285 (194r).

12 Hollander, op. cit. supra note 10, at I22-27.

${ }_{3}$ In re Weidberg's Estate, $x_{2}$ N.Y. Misc. 524, r5 N.Y.S. $2 d 252$ (1939).

14 In re Bold's Estate, I73 N.Y. Misc. 545, I8 N.Y.S. 2d 29I (I940); In re Landau's Estate, $x_{7}$ N.Y. Misc. 65I, 16 N.Y.S. $2 d 3$ (r939).

15 One court stated: "It is a matter of common knowledge that private ownership of property has been abolished in the Soviet Union," and withheld funds due a Soviet distributee. In re Landau's Estate, r72 N.Y. Misc. 651, 653, I6 N.Y.S. 2d 3, 6 (r939). The Soviet Union has not abolished private ownership of property, however, and the Soviets do have a system of inheritance, although the class of possible inheritors is more limited than in common-law countries. Hazard, Soviet Law: An Introduction, 36 Col. L. Rev. I236, I255 (1936); I Gsovski, Soviet Civil Law 627-5० (1948).

${ }^{16}$ In one case, for example, the court stated that a Soviet distributee whose share was $\$ 1500.00$ would receive only $\$ 300.00$ in rubles, the remainder being confiscated by the Soviet government. In re Bold's Estate, I73 N.Y. Misc. 545, r8 N.Y.S. 2d 29I (r940). 
Union. ${ }^{17}$ The emphasis in these cases shifted from a desire to assist beneficiaries to a policy of not assisting "unfriendly" nations. This latter approach was apparently abandoned in 1945 , when Soviet legatees and distributees were permitted to withdraw funds which had previously been withheld..$^{8}$ The courts decided that a new Soviet law permitted the beneficiaries involved to receive the full enjoyment of their property.

The early New York attitude toward residents of Soviet-controlled countries has recently been adopted by a New Jersey court. ${ }^{20}$ The New Jersey statute, ${ }^{2 x}$ dormant for ten years, was resurrected in $195^{\circ}$ and used to withhold funds from a Hungarian legatee, the court citing with approval the early New York decisions and disregarding later New York cases. ${ }^{22}$ The court declared that a communist system per se would not permit beneficiaries full enjoyment of their benefits. ${ }^{23}$ Such a declaration is unfortunate. In making judgments about political systems, in deciding the cases on the basis of a comparison to our own system of inheritance, courts drift away from the aims of the legislatures. Instead of determining an appropriate means of carrying out the wishes of the testator, the courts try to withhold aid from those countries whose political systems they dislike. Doubtless, refusal to transmit property normally going to an alien beneficiary, whether he would have received the benefits or not, will have some effect upon relations between this country and that of the alien beneficiary. Interruption of the flow of property by state legislatures and courts consciously implementing their views of the beneficiary's government will even more clearly have such an effect.

The New York and New Jersey legislatures expressed a desire to aid the alien beneficiary and to carry out the intent of the testator. An entirely different attitude is indicated by the "reciprocity statutes," popular among the western states. ${ }^{24}$ California's Probate Code, typical of these statutes, provides that

17 Sometimes the beneficiaries were treated as potential enemies. One court feared that funds remitted to the Soviet Union would be used to sabotage American industry. In re Landau's Estate, 172 N.Y. Misc. 65 1 , I6 N.Y.S. $2 d$ (1939).

${ }^{18}$ In re Landau's Estate, 187 N.Y. Misc. 925, 66 N.Y.S. 2d I7 (1946); In re Alexandroff's Estate, 6I N.Y.S. 2d 866 (x945); In re Adzericha's Estate, 6x N.Y.S. 2d 867 (1945).

19 The courts also gave weight to a certificate presented by the Soviet ambassador stating that Soviet beneficiaries were permitted full benefit, use, and control of property sent them. In re Alexandroff's Estate, 6r N.Y.S. 2d 866 (r945).

${ }^{20}$ The testator had named a Catholic orphanage in Hungary as residuary legatee. At the time of the probate proceedings, the orphanage was under state control. The.court decreed that funds should be withheld pending determination of whether the orphanage was the same institution as that named by the testator, and whether it would receive full benefit of the funds. In re Url's Estate, 7 N.J. Super. 455, 7I A. $2 \mathrm{~d} 665$ (I950).

${ }^{2 x}$ N.J. Rev. Stat. (Supp., I940) tit. 3, c. 26, § 2.r.

22 In re Url's Estate, 7 N.J. Super. 455, 473-76, 7r A. 2d 665, 676-77 (1950).

${ }_{23}$ The court described the Soviet property system in the language of In re Landau's Estate, 172 N.Y. Misc. $65 x, 653$, I6 N.Y.S. 2 d 3,6 (x939), quoted supra note 15 .

24 Ariz. Code Ann. (r939) c. 39, \& IIr; Cal. Prob. Code (Deering, I93I) § 259; Mont. Rev. Code Ann. (Choate \& Wertz, I947) tit. 9I, C. 5, $\$ 520$; Nev. Comp. Laws (Supp., I93I-4I) 
the right of a nonresident alien to inherit property situated in the United States is dependent upon a reciprocal right extended to American citizens by the alien's government. ${ }^{25}$ If no such reciprocal right exists, the alien is disinherited, and his intended benefit is treated as lapsed.

A dissimilarity to the New York and New Jersey statutes is apparent. In a brief submitted by the United States, the California act is described as "not an inheritance statute, but a statute of confiscation and retaliation. ${ }^{2{ }^{26}} \mathrm{The}$ California courts have thus disinherited all nonresident aliens whose governments do not treat American citizens in the manner prescribed in the statute. ${ }^{27}$ There was no attempt to protect the interests of the alien or to effectuate the wishes of the testator.

\section{II}

When states legislate on aliens' rights to legacies, they are entering an area usually thought to belong exclusively to the federal government. The executive department of the federal government is charged with the conduct of foreign affairs, free from state interference. ${ }^{28}$ The states do, however, retain exclusive control over matters of decedents' estates. ${ }^{29}$ When these two areas of the law overlap, as they surely must where alien beneficiaries are concerned, conflict is likely to result. State courts applying a reciprocity rule must sit in judgment on a foreign government, and decide whether it treats American citizens in a prescribed manner. The alien beneficiary, often through a representative of his

$\S 9894$; Okla. Stat. (I94I) tit. 60, § I2I; Ore. Comp. Laws Ann. (I940) tit. 6r, c. I, $\S$ Io7. Compare Conn. Gen. Stat. (r949) \& 7r66; La. Civ. Code Ann. (Dart, r932) art. 1490; Tex. Ann. Rev. Civ. Stat. (Vernon, 1925) art. I66, I77.

The Supreme Court of Oregon, in Namba v. McCourt, I8 5 Ore. 579, 204 P. 2d 569 (1949), found an Oregon statute withholding from aliens ineligible to United States citizenship the right to acquire interest in Oregon land invalid because it infringed the "equal protection" and "due process" clauses of the Fourteenth Amendment. Oregon's reciprocity statute was contained in the same chapter in which the land laws appeared. Ore. Comp. Laws Ann. (rg40) tit. 6x, c. I. The court found the entire chapter unconstitutional. Apparently the Oregon legislature felt that the reciprocity statute was excluded from the court's finding, however, for it repealed all the sections of the chapter except the reciprocity provision (Section ro 7 ). Ore. L. (1949) c. 350.

${ }^{25}$ Cal. Prob. Code (Deering, I93I) $\& 259$.

${ }^{26}$ In re Bevilacqua's Estate, I6I P. 2d 589, 593 (Cal., I945).

${ }^{27}$ An alien beneficiary was disinherited if he failed to present convincing eyidence that reciprocity existed. In re Bevilacqua's Estate, I6r P. 2d 589 (Cal., 1945) (Italian beneficiary); In re Corcofingas' Estate, 24 Cal. 2d 517, 150 P. 2d I94 (I944) (Greek beneficiary); In re Michaud's Estate, 53 Cal. App. 2d 835, 128 P. 2d 595 (r942) (French beneficiary); see In re Thramm's Estate, 67 Cal. App. 2d 657, I55 P. 2 d II9 (I945) (German beneficiary).

28 "Power over external affairs is not shared by the States; it is vested in the national government exclusively. It need not be so exercised as to conform to state laws or state policies. ..." United States v. Pink, 3I5 U.S. 203, 233 (r94I); United States v. Belmont, 30 I U.S. 324, 33x (1937).

${ }^{29}$ Consequently, a state may grant inheritance rights to all aliens, Blythe v. Hinckley, 180 U.S. 333 (rgor), or may, conversely, deny inheritance rights to all aliens. Terrace v. Thompson, 263 U.S. 197 (I923). 
government, has the burden of persuading the court that reciprocity exists between the two governments. ${ }^{30}$ Even if the alien wins his case, consular representatives of his government have gone through considerable expense and inconvenience, merely to convince a court that their nation will accord fair treatment to United States citizens. ${ }^{32}$ If the alien loses, the state court may have ruled that the foreign representatives have incorrectly stated their own inheritance law. Our State Department, maintaining friendly relations with the alien's government, may well be embarrassed by the "unfriendly" action of the state court. ${ }^{32}$ The latter may appear to the alien's government to be the action of the entire nation. In any event it is likely to engender resentment. American interests abroad may thus be materially affected by a retaliatory state statute purporting to regulate inheritance only.

The New York statute was not retaliatory, but was aimed primarily at implementing the intent of the testator. Nevertheless, this type of legislation, depriving a foreign government of property it would otherwise have received, could disrupt a uniform foreign policy as much as any reciprocity statute. The beneficiary's government will resent the deprivation, regardless of what considerations have brought it about.

The federal government has never objected to the New York law, however, apparently because its application has not conflicted with federal statutes. When federal regulations freezing foreign assets in this country went into effect in $1940,{ }^{33}$ the New York courts found themselves working within a framework of controls which had no effect on the operation of the state statute. The property was, as before, deposited with a named public officer in New York and held for the beneficiary. ${ }^{34}$ In addition to satisfying the New York statute, however, the alien had to secure a Treasury Department license to remove his property from the blocked account. Both could usually be accomplished in the same way. If the alien could prove that he had satisfied the New York statute by placing himself in a position to receive the full benefit of his property, it was virtually

${ }^{30}$ The California Probate Code (Deering, I93I) § 259.I, originally placed upon the alien the burden of convincing the court that reciprocity existed. In I945, the act was amended to shift the burden to the person contesting the alien's right to inherit. In I947, the act was was amended again to place the burden back upon the alien beneficiary. In re Giordano's Estate, 85 Cal. App. 2d 588, 193 P. 2d 77 I (x948). Other states have placed the burden of persuasion upon the alien. Bottomly v. Meagher County, II4 Mont. 220, I33 P. 2d 770 (I943); Nev. Comp. Laws (Supp., I93I-4I) §9894.0x; In re Braun's Estate, I6I Ore. 503, 90 P. 2d 484 (1939).

3x The Danish Consul-General in Chicago and the staff of the Danish legation at Washington, for example, took part in the case of In re Nielsen's Estate, II8 Mont. 304, I6 ${ }_{5}$ P. 2d 792 (1946). The Netherlands Embassy also has interceded on behalf of its nationals. In re Blak's Estate, 65 Cal. App. 2d 232, I5० P. 2d 567 (I944).

${ }^{32}$ The United States Attorney General has stated that the California statute "will be a recurrent source of diplomatic friction." Clark v. Allen, 33 I U.S. 503 (1947), petitioner's brief at 75 .

33 Exec. Order No. 8389 (April Io, I940), I Code Fed. Reg. I28 (Supp., I940).

${ }^{34}$ In re Plemich's Estate, 176 N.Y. Misc. 560,28 N.Y.S. 2 d 86 (I94I). 
certain that the federal government would have no objections to releasing it. 35

Nor was the New York statute an obstacle to federal action during the war. When the Office of the Alien Property Custodian was established in I942, ${ }^{36}$ many alien beneficiaries found the protection of the New York law removed from them. All property due enemy aliens would be vested indefeasibly in the Custodian. ${ }^{37}$ The New York law operated to place assets due an enemy beneficiary in a special account, to be held for him until after the war. The Alien Property Custodian then vested in himself all rights to the property, placing it forever beyond reach of the alien..$^{38}$

Under the reciprocity statutes, an entirely different situation was presented. If the statute of California, for example, were effectively applied, the alien's benefit lapsed. There were no assets for the Custodian to impound. The federal government, therefore, attacked the reciprocity statutes at every opportunity. One line of attack was to contend that the enemy country involved did grant inheritance privileges to United States citizens. ${ }^{39}$ The courts, however, often did not follow the federal government's recommendations. $4^{\circ}$

Another line of attack on statutes of the California type was to contend that they were unconstitutional on two grounds: first, because they violated treaty provisions with the country concerned; and, second, because they were an improper incursion by the states into the foreign policy field. In Clark $v$. Allen,,$^{4}$ the United States Supreme Court rejected the second contention com-

35 If, for example, the alien could manage to come to the United States, property could be released without violating the freezing regulations. Nor would the New York statute be a bar, since the alien would now have control of his property. See In re Alexandroff's Estate, 46 N.Y.S. 2d 298 (r944). This means could not be used to circumvent the California statute, however. Under California's Probate Code, the benefit would lapse immediately, and no change of position could alter the alien's legal status.

${ }^{36}$ Exec. Order No. 9095 (March II, I942), 7 Fed. Register I97I (x942).

37 Clark v. Continental Nat'l Bank of Iincoln, Neb., 88 F. Supp. 324 (Neb., 1949); Clark v. Edmunds, 73 F. Supp. $39^{\circ}$ (Va., I947); Application of Miller, 288 Fed. 760 (C.A. 2d, I923).

Payment to the Custodian could not be avoided by providing in the will that the executor should hold the property in trust until such time as conditions abroad had improved. In re Reiner's Estate, 44 N.X.S. 2d 282 (I943). Such a provision would satisfy the requirements of the New York statute, however. One testator copied the language of the New York law into his will; the court held that while the legacy need not immediately be impounded pursuant to the state statute, the Custodian might confiscate it if he wished. In re Van Dam's Estate, 43 N.Y.S. $2 d$ I84 (r943).

${ }^{38}$ The beneficiary may, however, contend that he was not an enemy alien within the meaning of the statute. The Custodian had provided administrative remedies, subject to judicial review, to correct improper seizures. Moreover, Congress and the Custodian were empowered to order, at a later date, compensation for seizures. Domke, Trading with the Enemy in World War II 260-72 (I943).

39 The United States claimed that "on July I, I94I, there was no civilized nation which did not grant to citizens of the United States the right to inherit from its nationals, with limitations, however, upon the inheritance of real property." In re Bevilacqua's Estate, 16I P. 2d 589, 595 (Cal., I945).

${ }^{40}$ See, for example, ibid., at 595-96.

${ }^{4 \mathrm{t}} 33$ I U.S. 503 (1947). 
pletely, and further held that under the treaty with Germany, ${ }^{42}$ the application of the California statute was only partially excluded.

The United States had claimed that California, by preventing a German national from inheriting an estate composed of real and personal property, had violated a treaty between Germany and the United States. The Court, interpreting the provisions of that treaty, concluded that under the circumstances of the case, California could prohibit the transmission of personal property to a German national, but that it was prevented by the treaty from restricting the right to inherit realty. ${ }^{43}$ Since the language used in the German treaty is identical to that used in eighteen other treaties now in force, ${ }^{44}$ the rule of Clark v. Allen is of wide application. Such a rule permits a state to deny all benefits to aliens in the majority of cases, since legacies of money, corporate shares, and bonds comprise much of the property left to aliens. 45

In answer to the foreign-policy contention, the Court declared that the regulation of inheritance is a function of the states, and, so long as there is no overriding federal policy in the form of a treaty, the state law will be controlling. The state of California had not negotiated with a foreign government, or entered into any compacts in violation of Article I, Section Io of the Constitution. The Court admitted that California's action "will have some incidental or indirect effect in foreign countries. But," the Court continued, "that is true of many state laws which none would claim cross the forbidden line." ${ }_{46}^{6}$

While state legislation does often affect an area of the law delegated to the national government, once that government decides to act, its laws are superior to those of the states. ${ }^{47}$ When the Court in Clark v. Allen held that state regulation of alien succession was permissible, since the federal government had not yet formulated a definite policy, the Court assumed that such a policy could exist only in a codified way, as in a treaty. Actually, however, the federal government promulgates a policy in an informal way during its everyday relations with a given country. If the federal government has adopted an official attitude of friendliness toward a foreign nation, then a state statute which serves to

${ }^{22} 44$ Stat. $2{ }^{2} 32$ (I923).

${ }^{43}$ The treaty with Germany, 44 Stat. 2132 (I923), the Court said, prevented a state from interfering with the right of German nationals in this country to bequeath personalty to German nationals who resided in Germany, but did not prevent a state from curtailing an American citizen's right to bequeath personalty to German nationals. The result may have been different if the word "person" had been used instead of "national," as it was in the clause concerning realty. Clark v. Allen, 33I U.S. 503, 514, 515 (1947).

44 These treaties are listed by Meekison, Treaty Provisions for the Inheritance of Personal Property, 44 Am. J. Int. L. 313, 3I4 (1950).

45 Tbid.

${ }_{4}^{6}$ Clark v. Allen, $33^{1}$ U.S. 503, $5^{\text {I }} 7$ (I947).

47 Pennsylvania, for example, enacted a statute providing for a system of alien registration that was stricter than that provided by the federal government. The statute was held unconstitutional in Hines v. Davidowitz, 3 I2 U.S. $5^{2}$ (1940). 
create any sort of ill will may properly be considered an unwarranted incursion by that state into the foreign affairs field. $4^{8}$

It is difficult to determine just how "incidental or indirect" an effect state action of this sort will have. But the fact that the states were prompted to enact these laws indicates that the flow of property to alien beneficiaries must be sizable and steady, and that the governments concerned will certainly not be uninterested. A decision to cut off the flow should, therefore, be made with an understanding of the over-all problem, with the interests of the entire nation in mind, and with a realization of the consequences which might follow.49 It should, in other words, be made by the federal government.

\section{UNCOMMUNICATED THREATS}

An uncommunicated threat is traditionally defined as the expression of an intention to harm a particular person which is never communicated to that person. ${ }^{\mathrm{I}}$ The threat comes before the court when the person who made it has been killed. The person toward whom the threat was directed is charged with murder and offers evidence of the threat in an attempt to substantiate his plea of self-defense. Uncommunicated threats are relevant to this issue because the expressed intention of the deceased tends to establish that he was the aggressor. ${ }^{2}$

${ }^{8}$ In discussing the relation between Congress and the President in the foreign affairs field, the Court has stated: "Not only ... is the federal power over external affairs in origin and essential character different from that over internal affairs, but participation in the exercise of the power is significantly limited. In this vast external realm, with its important, complicated, delicate and manifold problems, the President alone has the power to speak or listen as a representative of the nation." United States v. Curtiss-Wright Corp., 299 U.S. 304, 3I9 (I936). The states have been prohibited from interfering with the federal executive also. Thus, a state cannot refuse to give effect to the acts of recognized governments. United States v. Pink, 315 U.S. 203 (I94I); United States v. Belmont, 30I U.S. 324 (1937). Nor can states refuse to grant sovereign immunity to an agency of a recognized government. Mexico v. Schmuck, 293 N.Y. 264, 56 N.E. 2d 577 (I944); see Lamont v. Travelers Insurance Co., $28 \mathrm{x}$ N.Y. 362,24 N.E. $2 d$ 8I (1939). In line with its disposition to treat executive power as supreme in the field of foreign affairs, were the Court to decide that friendly relations with a foreign nation constitute a definite executive policy, state disability would seem to follow.

${ }^{49}$ In holding unconstitutional a California statute regulating immigration, the United States Supreme Court asked: "If [the United States] should get into a difficulty which would lead to a war, or to suspension of intercourse, would California alone suffer, or all the Union?" Chy Lung v. Freeman, 92 U.S. 275, 279 (1875).

The courts do not define uncommunicated threats, but the definition given is implicit in the application of the term to particular fact situations. Typical uncommunicated threat situations are: the deceased said that "he would kill defendant before he went to bed that night." Wiggins v. Utah, 93 U.S. 465,470 ( 1876$)$; "If I run in with him I am going to beat his brains out with this." (The speaker was swinging a rope with a half-pound weight attached while he spoke.) Salter v. State, 76 Ga. App. 209, 45 S.E. $2 d$ I06 (I947); "So sure as my name is Jim Fisk [it was] I will kill him." Stokes v. New York, 53 N.Y. 164, x74 (1873).

2 Wiggins v. Utah, 93 U.S. 465 (1876); State v. Vernon, x97 La. 867, 2 So. $2 d 629$ (194I); Banks v. Commonwealth, 227 Ky. 647, I26 S.W. 2d II22 (x939); Trapp v. New Mexico, 225 Fed. 968 (C.A. 8th, I915); Stokes v. New York, 53 N.Y. 664 (I873).

Evidence is relevant if it tends to make the truth of the proposition sought to be proved 